ISSN: 2146-3042

DOI: $10.25095 /$ mufad.510443

\title{
Geleceğin Kurumsal Raporlama Yaklaşımı Olarak Entegre Raporlama: Garanti Bankası Örneği
}

\author{
Seçil ÖZTÜRK*
}

\begin{abstract}
$\ddot{O} Z E T$
Entegre raporlama, kurumsal değer yaratma sürecine odaklanan, finansal ve finansal olmayan bilgiler arasındaki etkileşimi kuran, kuruluşun karşılaşması beklenen risk ve firsatlarını dikkate alan, kuruluş stratejisini yansitan bütünsel bir raporlama yaklaşımıdır. Kurumsal raporlamadaki mevcut sorunlara çözüm ve geleceğin raporlama yaklaşımı olarak entegre raporlama gösterilmektedir. Bu çalışmanın amacı; entegre raporlama yaklaşımı hakkında bilgi vererek, mevcut gelişmeleri ortaya koymak, Garanti Bankası'nın 2017 yll entegre raporunu incelemektir. Garanti Bankası'nın 2017 yllina ait ilk entegre faaliyet raporu IIRC tarafindan yayımlanan Uluslararast Entegre Raporlama Çerçevesiyle uyumludur. Dünya'da olduğu gibi ülkemizde de entegre raporlama gelişme aşamasında olup, entegre raporlamaya geçişin sağlanmasına yönelik çalışmalar devam etmektedir.
\end{abstract}

Anahtar Kelimeler: Entegre Raporlama, Sürdürülebilirlik, Kurumsal Raporlama.

JEL Sinıflandırmast: M40, M41, Q56.

\begin{abstract}
Integrated Reporting As The Future Of Corporate Reporting Approach: Garanti Bank Example

\section{ABSTRACT}

Integrated reporting is a holistic model which reflects corporate strategy that focuses on corporate value creation process, establishes the relation between financial and non-financial information and considers the expected risks and opportunities. Integrated reporting model proposed as reporting approach of the future and as a solution for present problems in corporate reporting. The aim of this study is to provide information for integrated report approach, to present recent developments of integrated reporting and to analyze a integrated report of Garanti Bank. Garanti Bank's first integrated annual report of 2017 is suited to the International Integrated Reporting Framework published by IIRC. As in the worl, as in our country, integrated reporting is in development stage and studies are ongoing to ensure the transition to integrated reporting.
\end{abstract}

Keywords: Integrated Reporting, Sustainability, Corporate Reporting.

Jel Classification: M40, M41, Q56.

Makale Gönderim Tarihi: 14.04.2018

Makale Kabul Tarihi: 29.05.2018

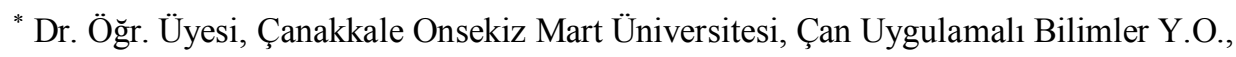
secilozturk@ comu.edu.tr, ORCID ID: 0000-0002-3357-3214
} 


\section{GíRiş}

Ekonomik ve politik krizler, küresel ısınma, çevresel sorunlar, istikrarsızlık, kurumlara karşı güvensizlik gibi nedenler çeşitli paydaşların kurumlardan bilgi talebini artırmış̧ır (RuizLozano ve Tirado-Valencia 2016:253). Organizasyonlar, risk yönetimi dahil olmak üzere karar alma, stratejik planlama, performans ölçümü süreçlerine çevresel ve sosyal göstergeleri gün geçtikçe daha fazla dahil etmek durumunda kalmışlardır (Adams ve Frost 2008:288). Ayrıca kurumsal sürdürülebilirlik politikalarının şirketlerin kurumsal itibarını artırdığı düşünülmektedir. Kurumsal itibarı artan ve çevresel, sosyal ve kurumsal yönetime ilişkin riskleri başarıyla yöneten şirketlerin marka değeri de artmakta ve bu şirket yatırımcıların ilgisini çekmektedir. Böylece rekabet üstünlüğü sağlanmış olacaktır. Kurumsal sürdürülebilirlik yaklaşımının şirketin karar alma süreçlerine dahil edilmesi, kısa vadede ek maliyetlere neden olabilir. Ancak uzun vadede şirketin maliyetlerini azaltarak, verimliliğini, kârlılığını ve performansını artırmasına yardımcı olacaktır (Gençoğlu ve Aytaç 2016:64)

Ekonomik, çevresel ve sosyal amaçların dengeli şekilde dikkate alınmasını savunan yaklaşım John Elkington tarafindan 1997 yılında "sürdürülebilirliğin üçayağı" (Triple Bottom Line) kavramı ile ortaya konmuştur. Buna göre; geleneksel muhasebe, finansal performansın yanında sosyal ve çevresel performansı da kapsayacak şekilde genişletilmiş̧ir. Uzun dönemde amaç; ekonomik, sosyal ve çevresel boyutlarda şirketlerin, tüm paydaşların ve genel olarak toplumun fayda sağlaması olduğu için, bu boyutlardan birinin göz ardı edilmesi tüm şirketin faaliyetlerini ve geleceğini tehlikeye atacaktır (Aras ve Sarığlu 2015:24). Dolayısıyla, şirketler ekonomik, sosyal, çevresel ve yönetsel etkilerinin kamuya açıklanabilmesi için sürdürülebilirlik, kurumsal sosyal sorumluluk, kurumsal yönetim ilkelerine uyum raporları vb. çeşitli raporlar hazırlamaktadırlar (Ruiz-Lozano ve Tirado-Valencia 2016:253). Ancak rapor sayısındaki artış maliyet ve zaman açısından şirketlere ilave yük oluşturmasının yanı sıra bilgi kullanıcılarının açık, öz, anlaşııı bilgi ihtiyacını karşılayamamakta (Kaya, 2015:127), bu raporların finansal raporlardan ayrı olarak yayınlanması finansal bilgiler ile finansal olmayan bilgiler arasında ilişkinin yeterince kurulamamasına ve şirketler arasında karşılaştırma yapılamamasına sebebiyet vermektedir. Bu durum finansal ve finansal olmayan bilgilerin birlikte sunulduğu tek bir rapora olan ihtiyacı ortaya çıkarmaktadır. Bu ihtiyaç sonucu entegre raporlama kavramı doğmuştur.

Entegre raporlama kavramı, teoride ve uygulamada çevre muhasebesi, sosyal sorumluluk muhasebesi, kurumsal yönetişim ve stratejik yönetim kapsamındaki sürdürülebilir amaçlı raporlama farklılıklarını gidererek, tümünü kapsamak ve bütüncül bir yaklaşım getirmek amacına dayanmaktadır (Yanık ve Türker, 2012:302). Eccles ve Krzus (2010:10), "One Report" isimli kitaplarında "birbirleri üzerindeki etkilerini gösterecek şekilde finansal ve finansal olmayan bilgilerin raporlanması" olarak entegre raporlama modelini sunmuşlardır (Dumay vd. 2016:167). Entegre raporlama kavramın ortaya atıldığ 1 ilk zamanlarda şuan benimsenen anlayışın ötesinde (Kaya vd. 2016:87) entegre rapor, işletmenin faaliyetlerine dair finansal raporların ve sürdürülebilirlik raporlarının tek bir rapor halinde sunulduğu rapor şeklinde ifade edilmiş (Karğın vd. 2013:28) olsa da Uluslararası Entegre Raporlama Konseyi (International Integrated Reporting Council -IIRC) tarafindan Uluslararas1 Entegre Raporlama Çerçevesi'nin (The International IR Framework) yayınlanmasıyla birlikte gelinen aşamada entegre rapor sadece finansal ve sürdürülebilirlik raporlarının birleşiminden ibaret olmayan kısa, orta ve uzun dönemde değer yaratmaya odaklı, finansal ve finansal olmayan bilgiler 
arasında etkileşime yer veren, daha geniş kapsamlı ve bütünsel bir rapor olarak yorumlanmaktadır. Entegre raporlamanın gelişiminde; Küresel Raporlama Girişimi (Global Reporting Initiative-GRI), Uluslararas1 Muhasebeciler Federasyonu (International Federation of Accountants -IFAC), Güney Afrika Entegre Raporlama Komitesi (The Integrated Reporting Committee of South Africa-IRC), Uluslararas1 Entegre Raporlama Konseyi (International Integrated Reporting Council-IIRC) başta olmak üzere çeşitli kurum ve kuruluşların önemli rolü bulunmaktadır.

$\mathrm{Bu}$ çalışmada entegre raporlama kavramı, entegre raporlamanın gelişimi, katma değer tablosunun entegre raporlamadaki önemi, Uluslararası Entegre Raporlama Çerçevesi incelenerek, Garanti Bankası 2017 yllına ait ilk entegre faaliyet raporu Uluslararası Entegre Raporlama Çerçevesi baz alınarak analiz edilmektedir. Garanti Bankası'nın 2013 yılında entegre rapor hazırlamak amaciyla IIRC pilot programına katılması, IIRC'nin Global A $\breve{g}$ (IR Network) ve Bankacılık Ağı (IR Banking Network) üyesi ve Entegre Raporlama Türkiye AğıERTA'nın kurucu üyesi olması sebebiyle yayımladığı ilk entegre raporu incelenmektedir ve entegre raporlama literatürüne katkı sağlaması amaçlanmaktadır.

\section{ENTEGRE RAPORLAMA YAKLAŞIMI}

Entegre raporlama, finansal ve finansal olmayan bilgileri kapsayan ve aralarında etkileşim kuran, kısa orta ve uzun vadede kurumsal değer yaratma sürecine odaklanan, kuruluşun karşılaşması beklenen risk ve firsatlarını dikkate alan, kuruluş stratejisini yansıtan geniş bakış açılı bütünsel bir raporlama yaklaşımıdır. Entegre raporlama yatırımcılar da dahil olmak üzere tüm paydaşlara finansal ve finansal olmayan bilgiler arasında bağlantı kurma, şirketin süreçlerini ve stratejilerini, kısa, orta ve uzun vadede ölçülebilir risk ve firsatlarını görme imkânı vermektedir. Entegre raporlama ile sunulan bilgiler ışı̆̆ında şirketin geçmiş performansını ortaya koyan fotoğrafı verilmekle birlikte, şirketin hedeflerine nasıl ulaşacağı, nasıl hayatta kalacağı ve nasıl değer yaratacağı da açıklanmaktadır.

Entegre rapor Mervyn King tarafindan "şirket faaliyetinin önemli finans ve sürdürülebilirlik meseleleri arasindaki bağlantiyı ve sürdürülebilirlik meselelerinin değer yaratımın devam ettirmek üzere uzun vadeli stratejiyle nasıl bütünleştirildiğini net olarak ifade ettiği bir rapor" şeklinde tanımlanmıştır. Entegre raporlama (www.entegreraporlamatr.org, 2017):

- $\quad$ Finansal rapor kullanıcılarına sunulan bilginin kalitesini yükseltmeyi,

- Kurumsal raporlamaya daha bütüncül bir yaklaşım getirmeyi,

- Kurumsal raporlamaya daha verimli bir yaklaşım getirmeyi,

- $\quad$ Finans, üretilmiş, fikri, insan kaynağı, sosyal, ilişkisel ve doğal sermaye tabanı için hesap verebilirliği ve yönetilebilirliği kuvvetlendirmeyi, edinmektedir.

Kısa, orta ve uzun vadeli değer meydana getirilmesini teşviki amaç

Entegre raporlamaya geçiş ile kısa dönemde hissedarlar için üretilen değere odaklanma düşüncesinden, uzun dönemde tüm paydaşlar için üretilen değere odaklanma düşüncesine, başka bir deyişle entegre düşünceye doğru bir değişim yaşanması beklenmektedir. Ayrıca entegre raporlamanın tüm paydaşlar ile ilişkileri ve bağlantıları daha açık şekilde göstermeye, kurumsal itibar riskini düşürmeye, daha iyi kararlar vermeleri 
açısından yöneticilere yardım etmeye, daha güçlü kurumsal kültüre sahip olmaya yardımcı olacağı düşünülmektedir (Dumitru ve Jinga, 2015:118). Ülkemizde entegre rapor anlayışının yerleşmesi açısından işletmelerin kurumsal yönetim yapısına uygun hale getirilmesi, küresel gelişmeler ışığında düzenlemelerin yapılması ve işletmelerin teşvik edilmesi gerekmektedir (Topçu ve Korkmaz, 2015:18).

\subsection{Entegre Raporlamada Katma Değer Tablosunun Yeri ve Önemi}

Staden vd. (2013:21) araştırmalarında katma değer tablosunun ve katma değer bilgisinin sürdürülebilirlik raporlamasının bir parçası olarak yararlı olabileceği amacından yola çıkarak, Küresel Raporlama Girişimi (Global Reporting Initiative-GRI) çerçevesinde de katma değer tablosuna benzer şekilde şirketin ürettiği ve paylaştırdığı değer hakkında bilgi istendiği için GRI veritabanında bulunan şirketler arasından Güney Afrika, Almanya, İtalya ve Birleşik Krallık olmak üzere 4 ülkeden toplamda 191 şirketin 2013 Ocak ayında yayınlanan sürdürülebilirlik raporlarını incelemiştir. Çalışmanın sonuçlarına göre diğer iki Avrupa ülkesine göre İtalya'da sürdürülebilirlik raporlarında katma değer tablosuna daha yüksek oranda rastlanmaktadır. İtalya ve entegre raporlamanın yüksek olduğu Güney Afrika'daki şirketlerin sürdürülebilirlik raporlarında katma değer bilgisi daha önemli yere sahiptir ve katma değer tablosu ve katma değer bilgisi sürdürülebilirlik raporlarının önemli bir parçası olarak dikkate alınmalıdır. Haller ve Staden (2014) çalışmalarında katma değer tablosunun entegre raporlama için etkili ve yararlı bir raporlama aracı olduğunu savunarak, bir katma değer tablosu önermişlerdir.

Katma değer, makro ve mikro ekonomik düzeyde iki şekilde tanımlanabilir. Makro ekonomik açıdan katma değer; üretim faktörlerine (emek, sermaye, doğa, teşebbüs vb.), üretime katılmaları karşıllğında ödenen payların (ücret, faiz, kira ve kar vb.) toplamı, mikro ekonomik açıdan ise şirket tarafindan oluşturulan mal/hizmetlerin satış bedelleriyle, bu mal/hizmetlerin maliyetleri arasındaki olumlu fark, başka bir deyişle üretim aracıllğ̆ ile mal/hizmetlere şirket tarafindan ilave edilen değerin ifadesidir (Öztürk, 2011;3-4). Şirket düzeyinde üretilen ve paylaştrıllan katma değer, ABD'de 1954'te Suojanen'nin "Girişim Teorisi" sonucunda ortaya çıkan (Malgwi ve Purdy, 2009;254) "katma değer tablosu" ile raporlanmaktadır. Katma değer; işletmenin iç ve dış çevresindeki paydaşların (hissedarların, çalı̧sanların, devletin, kredi verenler vb.) işletme üzerindeki haklarını göstermesi açısından da bir sosyal raporlama aracıdır(EK 1). Katma değer raporlama ile sadece işletme sahip ve ortaklarına "kâr" raporlamanın ötesine geçilerek, çalışanlar, kredi verenler, devlet ve işletmenin kendisi olmak üzere daha geniş bir paydaş grubu için üretilen refah sunulmaktadır (Mook vd., 2003;286). Katma değer bilgisi, dünyanın farklı ülkelerinde kurumsal sosyal sorumluluk raporlaması (CSR)'nın bir parçasıdır (Staden vd., 2013:1). Dolayısıyla entegre raporlarda katma değer bilgisine veya katma değer tablosuna (EK 1) yer verilmesi yararlı olabilir.

\section{LITERATÜR ARAŞTIRMASI}

Entegre raporlama konusunda literatürde birçok araştırma mevcuttur. Entegre raporlama araştırmaları çoğunlukla normatif görüşler sunmakta olup, entegre raporlama uygulamasına yönelik çalışmalara ihtiyaç duyulmaktadır (Dumay vd. 2016:166). Entegre raporlama konusunda yapılan bazı araştırmalara aşağıda yer verilmiştir: 
2014 y1lında, -Yeminli Yönetim Muhasebecileri Enstitüsü (The Chartered Institute of Management Accountants) ve Amerikan Yetki Belgeli Kamu Muhasebecileri Enstitüsü (AICPA) üyeleri tarafindan, Kuzey Amerika, Afrika, Asya Pasifik ve Avrupa'daki 350'den fazla üst düzey yönetici üzerinde araştırma yapılmıştır. Sonuçlara göre, yöneticilerin \%94 kurumsal raporlama aracılığıyla değer yaratımının etkin şekilde açıklanmasının önemli olduğunu ve \%92'si finansal ve finansal olmayan bilgilerin entegrasyonunun potansiyel faydaları olduğunu düşünmektedir. Ayrıca yöneticilerin \%63'ü entegre raporlamadan haberdar olduklarını ve \%80'i işletmelerinin başarıya ulaşmasında ER'nın potansiyelinin bulunduğunu belirtmiştir. Ancak bu olumlu bakış açısına rağmen \%56'lık bir çoğunluğun belirli bir süre içinde entegre raporlamayı kabul etmeye yönelik somut planlar yapmadığ belirlenmiştir. ER geçişi planlayanlar ise 2-3 yıllık süre içerisinde geçiş öngörmektedir(CGMA, 2014). Serafeim (2014), entegre raporlama uygulamasının firmanın yatırımcı tabanını nasıl etkilediğini araştıran çalışmasında, entegre raporlamayı daha çok benimseyerek uygulayan şirketlerin özellikle daha uzun dönemli yatırımcı tabanına sahip oldukları sonucuna ulaşmıştır. Havlova (2015:231-236), çalışmasında 2010 yılında IIRC'nin entegre raporlama ilkelerinin gelişimine zemin hazırlamak için başlattığı pilot programa katılan dünyadaki 100 şirketten 48 (28'i Avrupa, 8'i Amerika, 6'sı Asya, 4'ü Avusturalya ve Yeni Zellanda, 2'si Afrika) şirketin 2010-2014 yılı raporlarındaki değişimi incelemiş, entegre raporların benimsenmesi ile yayımlanan rapor sayısı ve kapsamının azaldığını, bilgi teknolojilerinin daha yaygın kullanılır duruma geldiğini belirlemişlerdir. Dumitru ve Jinga (2015:117) araştırmalarında bir Japon ilaç Firmasının (Takeda Pharmaceutical Company) 2006-2015 dönemine ait entegre raporlarını içerik analizine tabi tutmuş, şirketin entegre raporlamada tecrübeli olduğunu, Uluslararası Entegre Raporlama Çerçevesinin ilkelerini özümseme derecesinin yüksek olduğunu tespit etmiştir. Kaya vd. (2016) çalışmalarında 13 farklı ülkede bulunan 13 farklı işletmenin entegre raporlarını incelemiş ve entegre raporlarda değer, performans, sermaye öğeleri ve bu öğelerde oluşan etkiler gibi kavramsal değerlendirmelerin algılanmasında farkl1lıklar, entegre raporun diğer raporlara ilave mi yoksa kapsayıcı nitelikte mi olduğu konusunda da farklı uygulamalar tespit etmişlerdir. Gençoğlu ve Aytaç (2016:64-65) çalışmalarında BİST Sürdürülebilirlik Endeksine Kasım 2015-Ekim 2016 döneminde dahil olan şirketlerin 2009-2015 yıllarına ait yıllık faaliyet raporlarında çevresel sürdürülebilirlik konusunda çalışmaların yıllara göre arttığını, 2012 yılından itibaren tüm şirketlerin yıllık faaliyet raporlarında sosyal sürdürülebilirlik konusunda bilginin bulunduğunu ve bilgilerin 2015 yılına kadar artış gösterdiğini tespit etmişlerdir. Demirel ve Erol (2016:32) çalışmalarında, Küresel Raporlama Girişimi'nin (Global Reporting Initiative (GRI)) sürdürülebilirlik açıklamaları veri tabanından elde ettikleri verilere göre 1999-2015 Temmuz döneminde en fazla 2012 yılında entegre raporlamanın yapıldığını, entegre raporlama yapan şirketlerin çoğunun büyük ölçekli şirketler olduğunu, en fazla Avrupa bölgesinde entegre raporlama yapıldığını, en çok entegre rapor yayınlayan sektörün finans sektörü olduğu tespit etmişlerdir. Ruiz-Lozano ve Tirado-Valencia (2016) çalışmalarında endüstri sektöründe faaliyet gösteren farklı ülkelerden şirketlerin 2013 yılına ait raporlarını inceleyerek, entegre raporlama ilkelerine dikkat düzeylerini araştırmışlar, sonuçlara göre ilkelere uyum konusunda araştırma kapsamındaki şirketlerin çabasına rağmen "kısa ve öz olma" ilkesi başta olmak üzere şirketlerin entegre raporlama konusunda daha uzun bir yola ihtiyacı olduğunu tespit etmişlerdir. Yüksel ve Aracı (2017) çalışmalarında BİST Kurumsal Yönetim Endeksinde işlem gören 50 şirketin 2014 y1lı faaliyet raporlarının entegre raporlamaya uygunluk derecesini Entegre Raporlama Çerçevesi ilkelerini esas alarak incelemişlerdir. Sonuçlara göre, endekste işlem gören işletmelerin \%48'inin entegre raporlamaya uygun olduğunu ifade 
etmiş̧lerdir. Köse ve Çetinel (2017) çalı̧̧malarında Argüden Yönetişim Akademisi'nin 2015 yılı entegre raporunu, Ercan ve Kestane (2017a) çalş̧malarında Türkiye Sınai Kalkınma Bankası'nın 2016 yılı entegre raporunu ER Çerçevesine göre değerlendirmişlerdir. Yine Ercan ve Kestane (2017b) tarafindan, Türkiye'de 2016 yılında entegre raporlama yapan tüm işletmelerin raporları içerik analizine tabi tutulmuştur.

\section{ENTEGRE RAPORLAMANIN GELISŞIMI}

$\mathrm{Bu}$ başlık altında entegre raporlamanın doğuşu, dünyada ve ülkemizde gelişimi ve mevcut durumu açıklanmıştır.

\subsection{Entegre Raporlamanın Doğuşu}

Kurumsal raporlama, finansal raporlamadan entegre raporlamaya doğru bir gelişim göstermiştir. Entegre raporlamaya doğru gelişen kurumsal raporlama süreci Şekil 1'de gösterilmiştir.

\section{Şekil 1. Kurumsal Raporlamanın Evrimi}

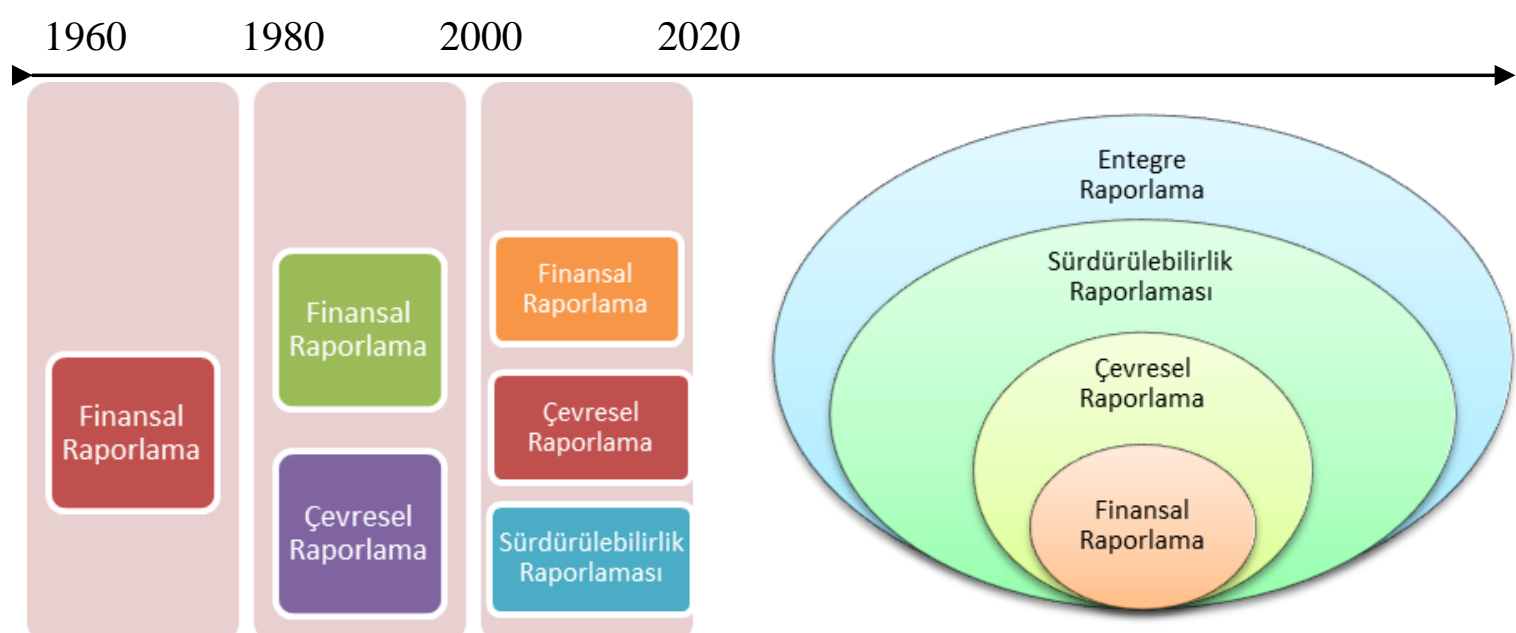

Kaynak: Aras ve Sarıoğlu (2015:38).

Entegre raporlamanın doğuşunda Güney Afrika'daki kurumlara yönelik olarak hazırlanan King raporları etkili olmuştur. 1994 yılında Nelson Mandela tarafindan Güney Afrika da kurumlara duyulan güvensizliği azaltabilmek amacıyla King Komitesi’ni kurması için Mervyn King görevlendirilmiş, 1994'de King I, 2002'de King II ve 2009 yılında King III Raporları yayımlanmıştır. Bu raporlara göre şirketlere sosyal, çevresel ve ekonomik sorumluluklarının sonuçları, finansal bilgileri ile finansal olmayan bilgilerini de raporlaması olanağı verilmiş̧tir. 2010 yılında ise dünyada ilk kez Güney Afrika'da, borsaya (Johannesburg Borsası) kote tüm şirketlerin entegre rapor yayımlanması, yayımlamayanların ise neden entegre rapor yayımlamadıklarını açıklaması zorunlu hale getirilmiş̧ir (www.entegreraporlamatr.org, 2018). Eccles ve Krzus (2015:31-32) entegre raporlamanın anlam ifade etmesini birbirini takip eden ve etkileşimli dört evrede açıklamışlardır. 


\begin{tabular}{llll} 
& \multicolumn{2}{c}{ Şekil 2. Entegre Raporlamanın Gelişimi } \\
Şirket Den eyimi & Uzman Yorumu & Kodlama & Kur umsallaşma \\
-Novozymes (2002) & -New Wine New Bottles: & -Güney Afrika Entegre & -King III (2009) \\
-Natura (2002) & The Rise of Non-Financial & Raporlama Komitesi & -AB Finansal \\
-Novo Nordisk(2004) & Reporting (2005) & Tartışma Metni (2011) & Olmayan \\
& - İntegrated Reporting: İssues & -IIRC Taslak Çerçevesi & Raporlama \\
& İmplications For Reporters & (2013) & Direktifi(2014) \\
& (2005) & -IR Çerçevesi (2013) & -BM Sürdürülebilir \\
& -One Report (2010) & & Kalkınma Hedefleri \\
& & & (2015) \\
\hline $\mathbf{2 0 0 2}$ & $\mathbf{2 0 0 5}$ & $\mathbf{2 0 1 1}$ & $\mathbf{2 0 2 0}$
\end{tabular}

Kaynak: Eccles ve Krzus (2015:32).

Şirket deneyimi evresi entegre raporlama fikrinin uygulamada yer alması, 2000'li yılların başında az sayıda şirketin (Novozymes 2002 yll, Natura 2002 yll, Novo Nordisk 2004 yilı) entegre rapor hazırlama çabalarıyla başlamıştır. Uzman yorumu evresinde danışmanlar, akademisyenler ve diğer uzmanlar şirket uygulamalarını gözlemleyerek entegre raporlama hakkında temel ilkeleri belirlemeye başlamışlardır. Entegre raporlamanın maliyetleri, faydaları, zorlukları ve bunların üstesinden nasıl gelineceği 2000'li yılların ortalarında teori kurma aşamasında başlamıştır. Bu evrede Allen L. White tarafindan 2005 y1lunda "New Wine, New Bottles: The Rise of Non-Financial Reporting" isimli makale, 2010 yılında Eccles ve Krzus tarafından yazılan "One Report" isimli kitap yayımlanmıştır. Kodlama evresi; şirketler, yatırımcılar, muhasebeciler gibi katılımcılarla birlikte çerçevelerin ve standartların geliştirilmesi aşamasıdır. Kurumsallaşma ise 2010'lu yılların başında başlamış ve bu evrede entegre raporlama uygulamasını daha elverişli hale getirmek, mevzuatı ve piyasa çevresini etkilemek üzerine çeşitli yasalar ve yönetmelikler yürürlüğe girmiştir (Eccles ve Krzus 2015:31). Örneğin; Avrupa Komisyonu tarafindan 2014 y1lı başında kabul edilen Finansal Olmayan Raporlama Direktifi ile entegre raporlama zorunlu kılınmamış olsa da Avrupa genelinde yaklaşı 6000 büyük şirketin finansal olmayan bilgilerini ve yönetim kurullarının dağılımını açıklamaları istenmiştir (Aras ve Sarığlu, 2015:73).

\subsection{Dünyada ve Ülkemizde Entegre Raporlamanın Gelişimi ve Mevcut Durumu}

Entegre raporlamaya geçmeden önce sürdürülebilirlik raporlarının dünyadaki gelişimine bakarsak; 1999-2015 yılları arasında dünyada 7.547 işletme, 24.405 sürdürülebilirlik raporu yayınlamış ve bu raporların 18.743'ü ise GRI raporudur (Özdemir ve Pamukçu 2016:19). KPMG International, GRI, Birleşmiş Milletler Çevre Programı (United Nations Environment Programme-UNEP) and Afrika Kurumsal Yönetim Merkezi (The Centre for Corporate Governance in Africa) tarafindan hazırlanan Carrots \& Sticks 2016 raporunda 2013 yılındaki duruma göre raporlama araçlarının sayısında artış olduğu ve araştırma yapılan 64 ülkede 383 sürdürülebilirlik raporlama aracı (248'i zorunlu, $135^{\prime}$ 'i gönüllü) tanımlandığ ifade edilmiştir. Özellikle Avrupa, Asya Pasifik, Latin Amerika'da sürdürülebilirlik raporlama araçlarındaki artış önemlidir. Hükümetler ve düzenleyici kuruluşlar, şirketleri yıllık raporlarında sürdürülebilirlik bilgisi açıklamaları için şirketleri teşvik etmekte ya da zorunlu tutmaktadır. (Carrots Sticks, 2016:9). 
2017 y1lı itibariyle Türkiye'nin de dahil olduğu 49 ülkedeki en büyük ilk 100 şirketin oluşturduğu 4.900 şirkette (N100) kurumsal sorumluluk (corporate responsibility) raporlama oranı \%75'tir. Bölgesel bazda bakıldığında oranın \%83'ünü Amerika, \%78'ini Asya Pasifik, \%77'sini Avrupa ve \%52'sini Orta Doğu-Afrika oluşturmaktadır. Dünyanın en büyük 250 şirketinde (G250) ise 2017 y1lı kurumsal sorumluluk (corporate responsibility) raporlama oranı \%93'tür. Yılllk finansal raporlarında kurumsal sorumluluk bilgisine en yüksek oranda yer veren on ülke şöyledir: Hindistan (\%98), Malezya (\%93), Birleşik Krallık (\%92), Güney Afrika (\%91), Tayvan (\%88), Danimarka (\%86), Fransa (\%83), Amerika (\%81), Norveç (\%81), İsveç (\%80). 2017 yılında hem G250 hem de N100 grubundaki şirketlerin \%14'ü entegre raporlama yapmış ve bu şirketlerin yaklaşık üçte ikisi de IIRC'ye atıf yapmıştır. Dünya çapında entegre raporlama yapan şirket sayısında 2017 yılında 2015 yılına göre artış yaşanırken özellikle Japonya $(+21)$, Brezilya $(+16)$, Meksika $(+16)$ ve İspanya $(+9)$ da entegre raporlamada önemli bir sıçrama yaşanmıştır. 2017 itibariyle N100 grubunda en fazla entegre rapor yayınlayan sırasıyla ilk on ülke şöyledir: Güney Afrika (90), Japonya (42), İspanya (36), Hollanda (36), Brezilya (22), Meksika (21), Güney Kore (17), Birleşik Krallı (15), İsveç (15), Polonya (15) (KPMG, 2017:9-24).

Entegre raporlama uygulama örneklerinin yer aldığı IR Example Database'de yıllara göre yayımlanan entegre rapor sayıları şöyledir: 2011 yılına ait 46, 2012 yılına ait 24, 2013 y1lna ait 47, 2014 y1lna ait 53, 2015 yllna ait 57, 2016 yllna ait 54 ve 2017 y1lına ait 16 (examples.integratedreporting.org/recognized_reports, 2018). IIRC tarafindan entegre raporlama yaklaşımını geliştirmek ve birlikte çalışmak amacıyla 1.750'den fazla katılımcısı olan (Business Network, Academic Network, Network for Professional Accountancy Bodies, Banking Network, Insurance Network, Investor Network, Pension Fund Network, Technology Initiative, Public Sector Pioneer Network) ağlar oluşturulmuştur (integratedreporting.org/ir-networks/, 2018).

Dünyada yaşanan bu gelişmeler ile birlikte ülkemizde de kurumsal sürdürülebilirlik raporları ile faaliyetlerinin ekonomik, çevresel ve sosyal boyutlarını kamuoyuna açıklamayı tercih eden işletme sayısı artmaktadır (Özdemir ve Pamukçu 2016:19). Ülkemizde 2005-2014 yıllarında toplam 72 işletme tarafindan, 181 adet (130 adeti GRI raporlama kilavuzunu baz almış) Kurumsal Sürdürülebilirlik Raporu yayınlanmıştır (Önce vd., 2015:230). Ülkemizde entegre raporlamaya yönelik bazı önemli gelişmeleri maddeler halinde sıralayabiliriz (www.entegreraporlamatr.org, 2018):

- 2011 yılında Türkiye Kurumsal Yönetim Derneği (TKYD) ve Sürdürülebilir Kalkınma Derneği (SKD) tarafından Türkiye'de entegre raporlama konusunda farkındalık sağlamak amacıyla bir çalışma grubu oluşturulmuştur.

- 2013 yılında Garanti Bankası ve Çimsa, entegre rapor hazırlamak amacıyla IIRC pilot programına katılmışlardır.

- $\quad 2015$ yılında TÜSİAD Prof. Dr Güler Aras ve Gaye Uğur Sarığlu tarafindan entegre raporlama konusunda literatüre Türkçe ilk rehber kazandırılmıştır.

- 2015 yılında Prof. Dr. Güler Aras başkanlığında; TÜSİAD, TKYD, Borsa İstanbul, IIRC Tükiye Büyükelçisi, Argüden Yönetişim Akademisi, Global Compact Network Türkiye, Garanti Bankası, SKD Türkiye ve Çimsa tarafindan Entegre Raporlama Türkiye Ağ1 (ERTA) oluşturulmuştur. 
- $\quad$ Argüden Yönetişim Akademisi (AYA), Adana Çimento Sanayii T.A.Ş., Çimsa Çimento Sanayii T.A.Ş., Aslan Çimento Sanayii T.A.Ş., Türkiye Sınai Kalkınma Bankası (TSKB) 2016 yılı entegre raporlarını yayınlamıştır.

- 2017 yılında Borsa İstanbul'da ERTA'nın kuruluşu ve entegre rapor hazırlayan kurumlar için gong töreni gerçekleştirilmiştir.

- Tüm bu gelişmelere ilave olarak ülkemizde entegre raporlamayı geliştirmek ve farkındalık sağlamak amacıyla akademik çalışmalar, toplantı ve paneller yapıllmış, yapılmaya da devam edilmektedir.

\section{ULUSLARARASI ENTEGRE RAPORLAMA ÇERÇEVESİ}

2008 yılında yapılan GRI (Global Reporting Initiative) Konferansında alınan stratejik hedeflerden biri olan, finansal raporlamayı ve ESG (Environmental, Social and Governance) raporlamasını etkin şekilde entegre edecek ve uluslararası platformda kabul görecek bir standardın 2020 yılına kadar hazırlanması önerisi entegre raporlama rehberinin ilk adımı olarak gösterilebilir (Gökmen, 2013:39). 2010 yılına gelindiğinde ise düzenleyici kurumlar, yatırımcılar, şirketler, standart belirleme otoriteleri, muhasebe uzmanları ve STK'lar tarafindan küresel bir koalisyon olan Uluslararası Entegre Raporlama Konseyi (International Integrated Reporting Council-IIRC) kurularak, 2011 y1lında Uluslararası Entegre Raporlama Çerçevesi'nin (International IR Framework); tartışma dokümanı yayımlanmıştır. Sonrasında birçok ülkeden özel, kamu, sektörü, STK temsilcileri ve akademisyenlerden gelen görüşler doğrultusunda Aralık 2013'de son haline getirilerek yayımlanmıştır (www.entegreraporlamatr.org/tr/,2017).

Çerçevede entegre rapor "bir kuruluşun stratejisinin, kurumsal yönetiminin, performansının, beklentilerinin kuruluşun dış çevresi bağlamında kısa, orta ve uzun vadede değer yaratmayı nasıl sağladığının kısa ve öz şekilde bildirilmesi” olarak tanımlanmıştır. ER çerçevesini temel dayanaklarından biri entegre düşüncedir. Entegre düşünce kuruluşun birim ve fonksiyonları arasındaki ilişkileri, kullandığı ya da etkilendiği sermaye öğelerini kısa, orta ve uzun vadede değer yaratma temelinde dikkate almasıdır (IIRC, 2013:33).

Entegre rapor kuruluş tarafindan yaratılan değerde payı ve etkisi bulunan dış çevre, sermaye öğeleri ve bunlar arasındaki etkileşimler hakkında bilgi sağlamayı da amaçlamaktadır (IIRC, 2013:10). Entegre raporlamaya ilişkin genel kabul görmüş, standart bir format bulunmamaktadır. Ancak çerçevede entegre raporun hazırlanmasında, sunulmasında yol gösterecek kılavuz ilkelere ve entegre raporun içerik öğelerine yer verilmiştir, bunlar Tablo 1'de özetlenmiştir. 
Tablo 1. Entegre Raporlama Çerçevesi Kılavuz İlkeler ve İçerik Öğeleri

\begin{tabular}{|l|l|}
\hline Kılavuz İkeler & İçrik Öğeleri \\
\hline - Stratejik Odak ve Geleceğe Yönelim & - Kurumsal Genel Görünüm ve Dış Çevre \\
- Bilgiler Arası Bağlantı & - Kurumsal Yönetim \\
- Paydaşlarla İlişkiler & - Iş̧ Modeli \\
- Önemlilik & - Riskler ve Fursatlar \\
- Kisa ve Öz Olma & - Strateji ve Kaynak Aktarımı \\
- Güvenilirlik ve Eksiksizlik & - Performans \\
- Tutarlılık ve Karşılaştırılabilirlik & - Genel Görünüş \\
\hline
\end{tabular}

Kaynak: Aras ve Sarığlu (2015:50).

Entegre raporu oluşturan bu ilke ve öğelerin temelini oluşturan üç kavram; "organizasyon ve diğerleri için değer yaratma", "sermaye öğeleri" ve "değer yaratma süreci”’dir (Aras ve Sarıŏlu, 2015:50).

Kuruluş, kendisi ve tüm paydaşlar (geniş anlamda toplum) için değer yaratır. Bu değer dış çevreden, paydaşlarla ve sermaye öğeleriyle ilişkilerden etkilenir. Kuruluşun, kendisi için değer yaratma yeteneği ve diğer paydaşlar için yaratılan değer ile ilişkilidir. Eğer kendisi için değer yaratma yeteneği açısından önemli ise entegre raporda yer verilmelidir. Kuruluş tarafindan yaratılan değer, kuruluşun faaliyet sonuçlarının sermaye öğeleri üzerinde oluşturduğu artışlar, azalışlar ve dönüşümler ile tespit edilebilir. Bu değer açıklanırken nitel ve nicel göstergeler kullanılabilir (IIRC, 2013: 10).

Çerçeve sermayenin daha etkili ve üretken şekilde dağılmasını sağlamaya yöneliktir. Sinıflandırma yapmak zorunlu olmamakla birlikte, çerçevede sermaye öğeleri şu şekilde sinıflandırılmıştır (IIRC, 2013:11-12):

- $\quad$ Finansal Sermaye: Bir kuruluşun mal üretmek ve hizmet sağlamak amacına yönelik olarak kullanımına sunulan finansman ile faaliyetler veya yatırımlar yoluyla edinilen fon havuzudur.

- $\quad$ Üretilmiş Sermaye: Bir kuruluşun mal üretmek ve hizmet sağlamak amacına yönelik olarak kullanımına sunulan üretilmiş fiziksel nesnelerdir (bina, ekipman vb.).

- $\quad$ Fikri Sermaye: Bir kuruluşa ait patent, telif hakkı gibi bilgiye dayalı maddi olmayan duran varlıklardır.

- İnsan Sermayesi: İnsanların yetenekleri, deneyimleri, motivasyonları, kuruluşa uyum sağlamaları, kuruluşu anlamaları, liderlik edebilmeleri, işbirliği yapabilmeleri vb. yeteneklerden oluşur.

- $\quad$ Sosyal ve İlişkisel Sermaye: Toplumlar, paydaş grupları ve diğer ağların kendi içlerindeki ve aralarındaki bilgi paylaşma yeteneğidir. Kuruluşun paydaşları ile ilişkileri, paylaşılan normlar, değerler, karşıllklı güven etkileşim isteği, kuruluşun geliştirdiği marka ve itibarla ilgili maddi olmayan duran varlıklar gibi kaynaklardır.

- Doğal Sermaye: Yenilenebilir ve yenilenemez doğal kaynaklar ve süreçlerdir. 
Girdi olarak sermaye öğeleri ile başlayan kuruluşun iş faaliyetleri sonucunda çıktıya dönüşen, sermaye öğeleri üzerinde etki göstererek sonuçları doğuran ve dış çevre ile sürekli etkileşim halinde bulunan değer yaratma süreci Şekil 3'de gösterilmiştir.

Şekil 3. Değer Yaratma Süreci

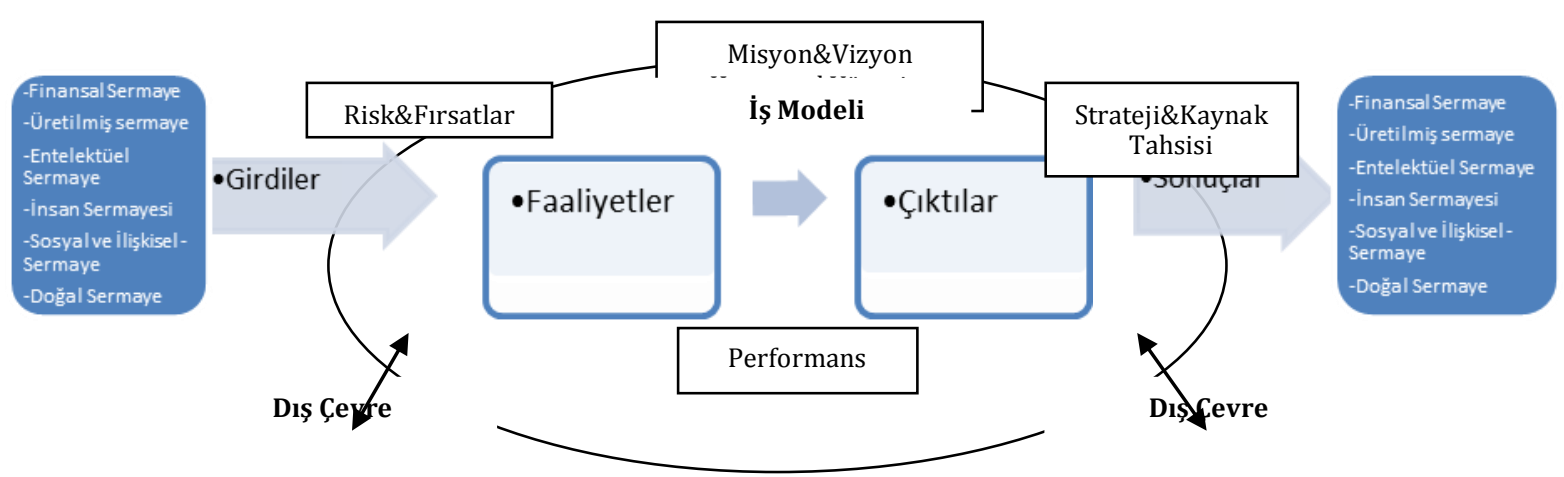

Kaynak: (IIRC, 2013).

Çerçevede kuruluşun iş modeline ayrı bir önem verilmiştir. Entegre raporlama yaklaşımına göre kurumsal yönetim yöntemlerini içeren kurumsal iş modelinin sunulması tüm paydaşlar arasındaki bilgi asimetrisinin minimize edilmesine, kuruluşun performansının kaynak kullanımı, riskler ve tehditler çerçevesinde çok yönlü, finansal ve finansal olmayan bilgiler temelinde irdelenmesi ve anlaşılabilmesine yardımcı olacaktır (Gökten, 2016:747). İşletme modeli, şirketin zaman içinde yarattığı değeri ve sürdürülebilirliğini değerlendirmek için yatırımcılar açısından da önemlidir (Mio vd., 2016:205). Çerçevede, kuruluşun uzun vadede yaşayabilirliğinin, iş modelinin değişime uyum sağlayabilme kapasitesinden etkilenebileceği belirtilmiştir (IIRC, 2013:13). Kılavuz ilkelere göre kuruluşlar arasında karşılaştırılabilirliğin sağlanmasında bilgilerin oranlar yoluyla sunulması da önemli katkı sağlayacaktır (IIRC, 2013:23).

\section{ENTEGRE RAPORLAMA ÖRNEĞİ: GARANTİ BANKASI}

Çalışmanın bu bölümünde entegre raporlamaya örnek olarak Garanti Bankası'nın 2017 yılına ait ilk entegre faaliyet raporu Uluslararası Entegre Raporlama Çerçevesi baz alınarak analiz edilecektir.

Garanti bankası, 1946 yılında Ankara'da kurulmuştur. 31 Aralık 2017 tarihi itibariyle konsolide aktif büyüklüğü ile Türkiye'nin en büyük ikinci özel bankası konumundadır. Garanti Bankasi; kurumsal, ticari, KOBİ, ödeme sistemleri, özel, bireysel ve yatırım bankacıllğı dahil olmak üzere bankacıllk sektörünün tüm iş kollarında faaliyette bulunmaktadır. Ayrıca Hollanda ve Romanya'daki uluslararası iştiraklerinin yanı sıra hayat sigortası ve bireysel emeklilik, finansal kiralama, faktoring, yatırım ve portföy yönetimi alanlarında öncü finansal iştirakleri ile bütünleşik bir finansal hizmetler grubudur. Banka 2010-2016 y1llarına ait sürdürülebilirlik raporu yayımlamış, Mart 2018'de ise 2017 yılına ait ilk entegre raporunu da yayımlanmıştır (www.garanti.com.tr/tr, 2018). 
Garanti Bankası'nın 2013 yılında entegre rapor hazırlamak amaciyla IIRC pilot programına katılması, IIRC'nin Global Ağı (IR Network) ve Bankacılık Ağ1 (IR Banking Network) üyesi ve Entegre Raporlama Türkiye Ağ1-ERTA'nın kurucu üyesi olması sebebiyle yayımlanan ilk entegre raporunun incelenmesi bu çalışmaya ayrı bir değer katacak ve entegre raporlama literatürüne katkı sağlayacaktır.

\subsection{Garanti Bankası Entegre Faaliyet Raporuna Genel Bir Bakış}

Garanti Bankası 2017 Entegre Faaliyet Raporunda, IIRC tarafindan yayımlanan entegre raporlama çerçevesine uyumlu olduğu belirtilmiştir. Ayrıca raporda yer verilen ve raporun uyumlu olduğu diğer ilke ve standartlar şöyledir: Küresel Raporlama İnisiyatifi (GRI) G4 Sürdürülebilirlik Raporlaması Kılavuzu, Birleşmiş Milletler Küresel İlkeler Sözleşmesi (UNGC), Kadının Güçlenmesi Prensipleri İlerleme Raporu (WEPs), Sürdürülebilirlik Muhasebesi Standartları Kurulu'nun (SASB) Ticari Bankalar için Geçici Standardı. Bağımsız denetim firması KPMG tarafindan denetlenen raporda finansal bilgiler için makul güvence, seçilmiş bazı finansal olmayan bilgiler için ise sınırlı güvence verilmiştir (Garanti Bankası Entegre Raporu, 2017:2).

Garanti Bankası'nın değer yaratma öyküsü, Uluslararası Entegre Raporlama Konseyi (IIRC) Başkanı Prof. Mervyn E. King Yönetim Kurulu Başkanı ve Genel Müdürün açılış mesajıyla başlayan raporun devamında faaliyet gösterilen ortam, riskler firsatlar, iş modeli, değer yaratımı, öncelikli konular, kurumsal yönetişim, stratejiler ve performans göstergelerine yer verilmiştir. Raporun sonraki bölümleri ise öncelikli konular temelinde devam etmiş belirlenen her bir öncelikli konu başlığı detaylı olarak incelenmiştir. En son finansal raporlara ve eklere yer verilerek, toplamda 455 sayfa olarak entegre faaliyet raporu sona ermiştir.

\subsection{Garanti Bankası Entegre Raporunun Değer Yaratma, Sermaye Öğeleri ve Değer Yaratma Süreci Bağlamında Analizi}

IIRC çerçevesine göre değer kuruluşun kendisi ve diğer paydaşlar için yaratılmakta ve değer yaratmanın merkezinde iş modeli bulunmaktadır. Dolayısıyla entegre raporda değerin nasıl ve kimin için yaratıldığı, iş modeli, hedefler, stratejiler, risk ve firsatlar, performans değerlendirme, diş çevre, değer yaratma kabiliyetinde etkisi olan paydaşlar ile ilişkiler, etkileşimler ve bunların sermaye öğeleri üzerindeki etkileri olmak üzere nitel ve nicel açıklayıcı ve değer yaratma kabiliyeti açısından önemli bilgilere yer verilmelidir.

Garanti Bankası entegre raporunda, faaliyet gösterilen dış çevre, hedefler ve öngörüler, riskler ve firsatlar, kurumsal yönetim yapısı ve performans verileri açılklanmıştır. Ticari faaliyetlerin başka bir ifade ile değer yaratımının uzun vadede sürdürülebilirliğinin sağlanması için risk yönetimi, iç denetim ve kontrol faaliyetlerinden de bahsedilmiştir. Raporun temelini, yöneticilerin ve dış paydaşların önemli olarak gördüğü ortak konular olan "öncelikli konular” oluşturmuştur. Raporda paydaşlar; müşteriler, çalışanlar, hissedarlar, yatırımcılar, analistler, tedarikçiler, STK ve dernekler, medya, üniversiteler, finans kurumları, kamu kuruluşları, uluslararası örgütler şeklinde belirtilmiştir. Paydaşları değer yaratma sürecine dahil edebilmek için paydaşlar ile diyalog kurulmuştur. Öncelikli konular, bu diyologlara dayalı olarak belirlenmiştir. Belirlenen öncelikli konular; finansal performans, müşteri deneyimi, dijital dönüşüm, insan kaynağına yatırım, kurumsal yönetişim ve risk yönetimi, sorumlu ve sürdürülebilir kalkınmadır (Garanti Bankası Entegre Raporu 2017:37- 
47). Ayrica belirlenen bu öncelikli konulara cevap olarak ve 17 Sürdürülebilir Kalkınma Hedefine (SKH) (2030-Sürdürülebilir Kalkınma Gündemi 2016) katkı sağlayan stratejik öncelikler belirlenmiştir (Garanti Bankası Entegre Raporu, 2017:40).

Tablo 2. Garanti Bankası'nın Stratejik Öncelikleri

\begin{tabular}{|c|c|}
\hline Ver & $\begin{array}{l}\text {-İş modeli ve süreçlerini operasyonel ve çevresel verimlilik bakış açısı ile sürekli } \\
\text { geliştirmek } \\
\text {-Maliyet ve gelir sinerjilerini gözetmek }\end{array}$ \\
\hline Diji & $\begin{array}{l}\text {-Dijital platformlara sürekli yatırım yaparak eşsiz müşteri deneyimi, işlem kolaylığı ve öncü } \\
\text { çözüm önerileri sunmak } \\
\text {-Dijital müşteri tabanını büyütmek ve satışlarda dijital kanalların payını artırmak }\end{array}$ \\
\hline $\begin{array}{l}\text { Çal } \\
\text { Mu }\end{array}$ & $\begin{array}{l}\text {-Çalışanların gelişimine, memnuniyetine ve esenliğine odaklanarak onlara yatırım yapmak } \\
\text {-Takım ruhuna sahip, ortak akıl ile hareket eden, sosyal sorumluluk sahibi ve sonuç üreten } \\
\text { ekipler oluşturmak } \\
\text {-Performansa dayalı, firsat eşitliği, çeşitlilik ve içeriden terfi odaklı, adil ve şeffaf bir } \\
\text { yönetim politikası benimsemek }\end{array}$ \\
\hline & $\begin{array}{l}\text { Tüm faaliyetlerin odağına müşterileri koyarak mükemmel bir deneyimi yaşatmak } \\
\text {-Müşterilere karşı her zaman açık, şeffaf ve sorumlu olmak } \\
\text {-Süreçleri müşterilerin gözüyle, hızlı, anlaşılır ve sade bir şekilde tasarlamak } \\
\text {-Sunulan çözümlerle finansal okuryazarlığı, sağlığı ve kapsayıcıllğı destekleyerek, } \\
\text { müşterilerin bilinçli kararlar almasına yardımcı olmak } \\
\text {-Müşteriler ile beklentilerini aşarak ve memnuniyetlerini artırarak, güvene dayalı ve uzun } \\
\text { soluklu ilişkiler kurmak } \\
\text {-Müşterilerin işlerini sürdürülebilir bir şekilde büyütmeleri için yenilikçi çözümler ve } \\
\text { öneriler sunmak }\end{array}$ \\
\hline $\begin{array}{l}\text { Optimum } \\
\text { Sermaye } \\
\text { Kullanımı } \\
\end{array}$ & $\begin{array}{l}\text {-Sermayeyi etkin kullanarak yaratılacak değeri en üst düzeye çıkarmak } \\
\text { - Gerçek bankacılık ilkesiyle disiplinli ve sürdürülebilir büyümeye odaklanmak } \\
\text {-Sağlam aktif kalitesine bağlılığı korumak }\end{array}$ \\
\hline $\begin{array}{l}\text { Sorumlu ve } \\
\text { Sürdürülebilir } \\
\text { Kalkınma }\end{array}$ & $\begin{array}{l}\text {-Vazgeçilmez değerleri güçlendiren, gelişmiş bir kurumsal yönetişim modeli uygulamak } \\
\text {-Tüm paydaşlara karşı güven, doğruluk, hesap verebilirlik ve şeffaflık ilkeleriyle hareket } \\
\text { etmek } \\
\text {-Finansal ve finansal olmayan riskleri dünya standartlarında entegre yöneterek etkin risk } \\
\text { yönetimini sağlamak } \\
\text {-Etki odaklı yatırım ilkelerini gözeterek verdiğimiz kredilerle ortak değer yaratmak } \\
\text { - Stratejik ortaklıklarla pozitif değişime öncülük etmek } \\
\text { - Öncelikli konularda etkili sonuçlara ulaşan toplumsal yatırım programlarına odaklanmak }\end{array}$ \\
\hline
\end{tabular}

Kaynak: Garanti Bankası Entegre Raporu (2017:46-47).

Raporda, stratejik önceliklerin Bankanın iş modelinin temelini oluşturduğu ifade edilmiştir. Stratejik önceliklerin sonuçlar ile ilişsisi 2017 performans göstergeleri başlığında ortaya konmuştur.

Tablo 3. Garanti Bankası 2017 Y1lı Stratejiler ve Çıktılar

\begin{tabular}{|c|c|}
\hline Stratejiler & Çıktılar \\
\hline $\begin{array}{l}\text { Müşteri } \\
\text { Deneyimi }\end{array}$ & $\begin{array}{l}\text {-Rakip bankalar arasında en yüksek net tavsiye raporu } \\
\text {-15 milyondan fazla müşteri } \\
\text {-Engelli dostu atm sayısı } 3.824 \text { (Tüm ATMlerin \%76'sı) }\end{array}$ \\
\hline $\begin{array}{l}\text { İnsan } \\
\text { Kaynağına } \\
\text { Yatırım }\end{array}$ & $\begin{array}{l}\text { - Bankacılık sektöründeki en yüksek çalışan bağlılığı seviyesi (65) } \\
\text {-Çalışan başına ortalama } 36 \text { saat eğitim } \\
\text {-Yüksek performans çalışan devinim hızı }(\% 2,3) \\
\text { - Üst ve orta yönetimde kadın çalışan oranı } \% 41\end{array}$ \\
\hline Dijital & -Türkiye'de gerçekleşen dijital işlemlerin 1/4'ü Garanti üzerinden gerçekleşmiştir \\
\hline
\end{tabular}




\begin{tabular}{|c|c|}
\hline Dönüşüm & $\begin{array}{l}\text {-Dijital satışların toplam satışlar içerisindeki payı 1/4'ten 1/3'e yükselmiştir } \\
\text {-Nakit hariç finansal işlemlerde dijital kanalların payı } \% 95\end{array}$ \\
\hline $\begin{array}{l}\text { Sorumlu ve } \\
\text { Sürdürülebilir } \\
\text { Kalkınma }\end{array}$ & $\begin{array}{l}\text {-Etki odaklı kredi tutarı 9,3 milyar tl (kümülatif) } \\
\text {-Garanti'nin dahil olduğu sürdürülebilirlik endeksi sayısı } 6 \\
\text {-Toplumsal programlara yatırım tutarı } 20,3 \text { milyon tl } \\
\text {-Kredilerde, kredi sözleşmelerine çevre ve sosyal ilkelerin eklenme yüzdesi } \% 100\end{array}$ \\
\hline $\begin{array}{l}\text { Finansal } \\
\text { Performans }\end{array}$ & $\begin{array}{l}\text {-Ortalama aktif kârlılı̆̆ } \% 1,9 \\
\text {-Ortalama özkaynak kârlılı̆̆ } \% 16,6 \\
\text {-Takipteki krediler oranı \%2,6 } \\
\text {-Sermaye yeterlilik rasyosu \%16,8 } \\
\text {-Çekirdek sermaye oranı \% } 14,7 \\
\text {-Temel bankacılık gelirleri /ortalama aktifler \% } 2,9 \\
\text {-Gider/gelir oran } \% 46,2\end{array}$ \\
\hline
\end{tabular}

Kaynak: Garanti Bankası Entegre Raporu (2017:50-51). verilmiştir.

Bankanın iş modeli ve değer yaratım sürecinin rapordaki şematik gösterimi aşağıda

\section{Şekil 4. Garanti Bankası Değer Yaratım Süreci}

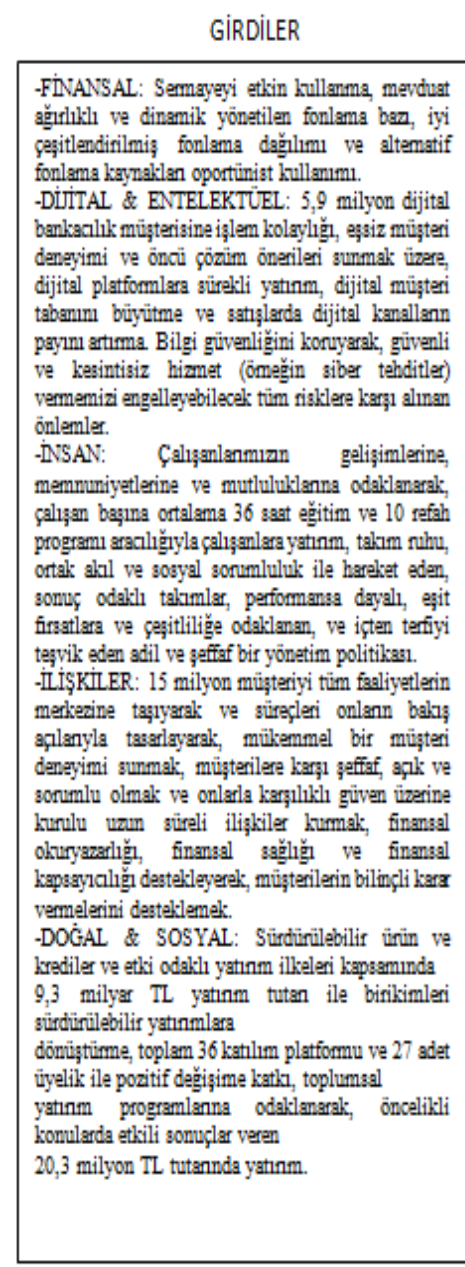

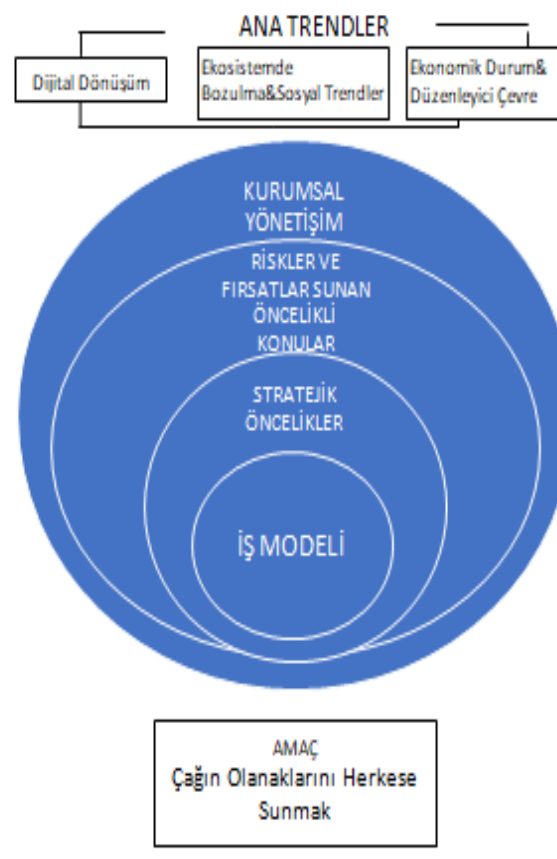

Kaynak: Garanti Bankası Entegre Raporu (2017:40-42).
YARATILAN DEǦER

-FINANSAL: Nakdi ve gayri nakdi lesediler araclyyla ekonomiye 285,5 milyar TL (75,6 milyar ABD dolan) destelk, \%16,6 Ortalama Ozkaynak Kârlliğı̆, \%1,9 Ortalama Altif Kârllliğ üretirken, Sermave Yeterliliği \%16,8 ve Çelirdel: Sermaye Rasyous \%14,7 2017 som itibanyla, Garantinin piyasa degeri 45 milyar TL (12 milyar $A B D$ dolan) seviyesine ulaşmı ve Geranti $\% 27,59$ kâr payl ödeme oraning teksabil eden hisse bagina 0,41667 TL brit temetti ademesini ortaklannin onsyina sunmuģtur.Ekonomiye ve topluma, ortaklara kâr payı ödemeleri, çalı̨anlara ücretler, tedarikçilere ödemeler ve hükümetlere vergi ödemeleri.

-DISTAL \& ENTELEKTUEL: Dijital kanallara yatınm sonuounda mügteri bilgilerinin gizliligyle ilgili veri sıantus yaganmazken dijital kanallar üzerinden sahglar toplam satı̧lann 1/3'üne yüksselmiģtir, Dijitalleşmenin öncisü olarak en geligkin dijital çözimlergiçlendiriyor ve son telnolojik geligmeler

-INSAN: 18.851 kiģi için istihdam yaratıken, firsat eşitliğ ve mesleki geligimin sağlanmas yönundeki çabalar, calıgan bağlilığında yüksek skor, çalıgan devir oranin dügük olmaoma sathada bulunuyor. \%41 üst ve orta sevive yönetici kadin çalıgan oraniyla ve kadinlann kariyerlerinde ilerlemesini teşvik eden çasitli girigimlerle, Garanti Türkiyeden Bloomberg Cinsiyat Egitlig. Endelksi'ne gimeye hak kazanan telk sirlket.

-IISSTKILER: Güvene dayalı iligkiler, özel rakip bankalar rasinda en yüksek Net Tavsiye Skon, is modelimizin temelindeki mügteri deneyimi odakllilı̆.. Finanal oluryazarlk, finansal sağllk ve finansal kapsayicliğ desteklemeye yönelik çabslar, tasamuf ürünlerini kullanmaya baglayan 809.397 mügterinin hayatna dolunabilmek. DOGAL \& SOSYAL: Etki odaklı yatınm ilkeleri ve yenilenebilir enerji alanina sağlanan finansman, faaliyettelki toplam kurulu gice istingden 5,4 milyon ton CO2e sera gan emisyonunun engellenmesi, yeni proje finansman tachhitlerinde eneji üretim portfoyü Kassam 3 ayalizi 'suif', kathlım falivetlerinin. SKH'ye kathıda bulunmayı amaclayarak hamrlanan 8 adat politika/ görüs yazusmun oluşmas ve 3 farkhl zorluğu agmayı hadefleyen toplumas yatunm programlan ile Yatunm Sosyal Getirisi olarak 2 den fanla degere ulasmas gibi calnsmalann bir sonucu olaral; Granti, onde gelen alth sürdirilebilirlik endelssinde yer almava hak kanarmiatif 
IIRC, kuruluşları sermaye öğelerini sınıflandırma konusunda zorunlu tutmamakla beraber sermaye öğelerini finansal, üretilmiş, fikri, insan, sosyal ve ilişkisel, doğal sermaye olmak üzere altı ayrı başlıkta ele almıştır. Garanti bankası kendi iş modeline göre farklı bir sınıflandırma yapmıştır ve sermaye öğelerini finansal, dijital ve entelektüel, insan, ilişkiler, doğal ve sosyal olmak üzere beş başlıkta toplamıştır. Ayrıca raporda semboller ile gösterilen yaratılan değerlerin sürdürülebilir kalkınma hedefleriyle ilişkisi aşağıda tablolaştırılarak verilmiştir.

Tablo 4. Sermaye Öğelerinin SKH'lere Katkısı

\begin{tabular}{|l|l|}
\hline Sermaye Öğeleri & Sürdürülebilir Kalkınma Hedefleri \\
\hline Finansal & İnsana yakışır iş ve ekonomik büyüme \\
\hline Dijital & Sanayi, İnovasyon ve Altyapı \\
\hline İnsan & $\begin{array}{l}\text { Nitelikli Eğitim, Cinsiyet Eşitliği, İnsana Yakışır İş ve Ekonomik Büyüme, Barış ve } \\
\text { Adalet }\end{array}$ \\
\hline İlişkiler & $\begin{array}{l}\text { Cinsiyet Eşitliği, İnsana Yakışır İş ve Ekonomik Büyüme, Sanayi, İnovasyon ve Altyapı, } \\
\text { Eşitsizliklerin Azaltılması }\end{array}$ \\
\hline Doğal ve Sosyal & $\begin{array}{l}\text { Nitelikli Eğitim, Temiz Su ve Hijyen, Erişilebilir ve Temiz Enerji, İnsana Yakışır İş ve } \\
\text { Ekonomik Büyüme, Sürdürülebilir Şehir ve Yaşam Alanları, Sorumlu Üretim ve } \\
\text { Tüketim, İklim Eylemi, Sudaki Yaşam, Karasal Yaşam, Hedefler İçin Ortaklık }\end{array}$ \\
\hline
\end{tabular}

Kaynak: Garanti Bankası Entegre Raporu (2017:43).

İş modelini, müşteri ihtiyaçlarını ve memnuniyetini işin merkezine alan, müşteri odaklı ve yenilikçi olarak ifade eden Garanti Bankası (Garanti Bankası Entegre Raporu, 2017:67), entegre raporu, IIRC ER Çerçevesi dahilinde temel kavramlar, kilavuz ilkeler ve içerik öğelerine uygun olarak hazırlanmıştır.

\section{SONUÇ VE ÖNERILLER}

20. yüzyılın son çeyreğinden bu yana uluslararası ticaret hacmindeki artış ve sermaye piyasalarında yaşanan büyük gelişmelere rağmen ekonomik ve finansal krizler, küresel ısınma ve çevre sorunları şirketlere olan güveni azaltmıştır. Şirketler yatırımcılarının ve toplumun güvenini kazanmak, şeffaflığ 1 ve hesap verilebilirliği sağlamak için ekonomik, sosyal, çevresel etki ve sorumluluklarını raporlamaya yönelmiştir. Böylece kurumsal raporlamada finansal raporların yanında kurumsal yönetim ilkelerine uyum raporları, sürdürülebilirlik raporları, kurumsal sosyal sorumluluk raporları vb. yayımlanmaya başlanmıştır. Ancak şirketlerin yayımladığı rapor sayısındaki ve çeşidindeki artış bilgi kirliliğine yol açmış, raporların karşılaştırılabilirliğini olumsuz etkilemiştir. Ayrıca bu raporlarda finansal ve finansal olmayan bilgiler arasında ilişki yeterince kurulamamış, şirketler daha çok geçmiş performanslarına odaklanmıştır. Gelinen bu aşamada mevcut sorunlara çözüm ve geleceğin raporlama yaklaşımı olarak entegre raporlama gösterilmektedir.

Entegre raporlama, finansal raporlar ile sürdürülebilirlik raporlarının bir araya getirilmesinden öte finansal ve finansal olmayan bilgileri kapsayan, aralarında etkileşim kuran ve kurumsal değer yaratma sürecine odaklanan bir raporlama yaklaşımıdır. Entegre raporda geçmiş performansa yer verilirken, kısa, orta ve uzun dönemde şirketin hedeflerine nasıl ulaşacağı, nasıl hayatta kalacağ1 ve nasıl değer yaratacağı da açıklanarak, geniş bir bakış açısı sağlanmaktadır. Entegre raporlama, yatırımcılar da dahil olmak üzere tüm paydaşlara finansal ve finansal olmayan bilgiler arasında bağlantı kurma, şirketin süreçlerini ve stratejilerini, kısa, 
orta ve uzun vadede ölçülebilir risk ve firsatlarını görme imkânı vermektedir. Nasıl ve kimin için değer yaratıldığı, değer yaratma süreci, sermaye öğeleri entegre raporun temelini oluşturmakta, değer yaratma sürecinin merkezinde ise kuruluşun iş modeli bulunmaktadır. Entegre raporda risk ve firsatlar, stratejiler, paydaşlar, paydaşlar ile etkileşimler, kurumsal yönetim, sermaye öğeleri, iş modeli, değer yaratma süreci, performans göstergeleri ve etkileşimlere yer verilmelidir. Böylece, entegre raporlama ile kuruluşta bir bütün olarak ilişkilerin, faaliyetlerin ve etkileşimlerin değer yaratma süreci üzerindeki etkileri, kuruluşun iş modeli ve stratejileri raporlanmış olacaktır.

Bu çalı̧̧mada, Garanti Bankası'nın 2017 yılına ait ilk entegre faaliyet raporu IIRC tarafindan yayımlanan Uluslararası Entegre Raporlama Çerçevesi baz alınarak analiz edilmiştir. Rapor, Entegre Raporlama Çerçevesine uygundur. Raporda, "öncelikli konular" adı altında yöneticilerin ve dış paydaşların önemli olarak gördüğü ortak konular belirlenmiş ve rapor bu konular üzerine dayandırılmıştır. Paydaşlarla etkileşim ile öncelikli konuların belirlenmesi sonrasında bu konulara cevap olarak "stratejik öncelikler" belirlenmiştir. Dolayısıyla, raporda kılavuz ilkelerinden "stratejik odak ve geleceğe yönelim", "önemlilik" ve "paydaşlarla ilişkiler"e ayrı bir önem verildiği söylenebilir. Ayrıca, rapor tüm içerik öğelerini de karşılamaktadır. Sermaye öğeleri IIRC'nin sınıflandırmasından (finansal, üretilmiş, fikri, insan, sosyal ve ilişkisel, doğal sermaye) farklı olarak, Garanti Bankası tarafindan kendi iş modeline göre finansal, dijital ve entelektüel, insan, ilişkiler, doğal ve sosyal olmak üzere beş başlıkta ele alınmıştır. Bankanın iş modeli ve değer yaratım süreci şematik olarak gösterilmiş olsa da iş faaliyetleri iş modeli şemasına dahil edilmemiştir. İş faaliyetlerinin, stratejilerin, paydaşların, risk ve firsatların aralarında bağlantılar dikkate alınarak özet şekilde iş modeli şemasına dahil edilmesinin raporun anlaşllabilirliğini artıracağ düşünülmektedir. Ayrıca entegre raporun "kısa ve öz olma" ilkesi bağlamında bilgi kullanıcılarının raporu daha net kavraması için verilen bilgilerin daha kısa ve özet şekilde verilmesi yararlı olacaktır.

Sonuç olarak; dünyada ve ülkemizde entegre raporlama henüz gelişme sürecindedir. Dünya'daki gelişmelere uyum sağlamak ve ülkemizde entegre raporlamanın gelişme sürecini hızlandırmak için düzenleyici ve denetleyici kurumlar tarafından kuruluşları entegre raporlama konusunda teşvik edecek çalı̧̧malara ihtiyaç vardır. Entegre raporlarda gerek sektörel olarak gerekse aynı sektörde faaliyet gösteren kuruluşlar arasında farklıllklar bulunmaktadır (Ercan ve Kestane, 2017b). Dolayısıyla entegre raporların sektörel bazda standart formatlarının oluşturulması raporlar arasında karşılaştırılabilirliğin sağlanması ve raporlama eksikliklerinin önlenmesini sağlayacaktır. Entegre raporlama mikro düzeyde ekonomik, sosyal ve çevresel boyutlarda üretilen değere odaklanmaktadır. Katma değer tablosunun şu haliyle sürdürülebilirliğin üç ayağı olan ekonomik, sosyal ve çevresel boyutların tümünde üretilen değeri tam olarak göstermesi mümkün olmasa da sadece hissedarlar ile sınırlı kalmayarak daha geniş bir paydaş grubunu hedef alması açısından entegre raporlarda katma değer tablosunun faydalı bir bilgi sağlama yolu olacağı söylenebilir. 


\section{KAYNAKLAR}

Adams, Carol A.- Frost, Geoffrey R. (2008), "Integrating Sustainability Reporting Into Management Practices”, Accounting Forum, No:32, pp. 288-302.

Aras, Güler -Sarığlu, Gaye Uğur (2015), “Kurumsal Raporlamada Yeni Dönem: Entegre Raporlama”, TÜSİAD, Yayın No:T/2015, İstanbul.

Carrots- Sticks (2016), "Global Trends in Sustainability Reporting Regulation and Policy", Çevrimiçi https://assets.kpmg.com/content/dam/kpmg/pdf/2016/05/Carrots-Sticks2016 FINAL. PDF (5 Nisan 2018).

CGMA (2014), “The IR Landscape:Executive Perceptions of İntegrated Reporting”, http://www.cgma.org/Resources/Reports/DownloadableDocuments/Integratedreporting-briefing.pdf

Demirel, Burcu-Erol, İbrahim (2016), "Investigation of Integrated Reporting As a New Approach of Corporate Reporting", International Journal of Business and Social Research Vol:6, Issue:10, pp.32-46.

Dumay, John-Bernardi, Cristiana-Guthrie, James-Demartini, Paola (2016), "Integrated reporting: A Structure Literature Review", Accounting Forum, Vol:40, Issue:3, pp.166-185.

Dumitru, Madalina-Jinga, Gabriel (2015), "Integrated Reporting Practice for Sustainable Business: A Case Study", Audit. Financiar, No:7, Vol:13, pp. 117-125.

Eccles, Robert G.-Krzus, Michael P.(2015), The Integrated Reporting Movement : Meaning, Momentum, Motives, and Materiality, John Wiley \& Sons, New Jersey.

Entegre Raporlama Türkiye Ağ1- ERTA, www.entegreraporlamatr.org (20 Mart 2018).

Ercan, Cuma-Kestane, Ali (2017a) "Kurumsal Raporlamada Yeni Bir Yaklaşım Olarak Entegre Raporlama Ve Bir Vaka Çalışması", ASSAM Uluslararası Hakemli Dergi International Refereed Journal, Cilt 4, Say1 8, ss.13-29.

Ercan, Cuma-Kestane, Ali (2017b) “Entegre Raporlama Ve Türkiye'deki Uygulama Örnekleri Üzerine Bir Araştırma", Kırklareli Üniversitesi İktisadi ve İdari Bilimler Fakültesi Dergisi, Cilt: 6, Say1: 4, ss.73-86.

Garanti Bankası Entegre Faaliyet Raporu, (2017).

Garanti Bankası, Çevrimiçi www.garanti.com.tr/tr, (10 Nisan 2018).

Gençoğlu, Ümit Gücenme-Aytaç, Alp (2016), “ Kurumsal Sürdürülebilirlik Açısından Entegre Raporlamanın Önemi ve BIST Uygulamaları", Muhasebe ve Finansman Dergisi, Say1:72, ss.51-66. 
Gökmen, Elif Özkul (2013), “Sürdürülebilirlik ve Raporlama Konferansı” Kurumsal Yönetim Dergisi, Say1:20, ss.38-40.

Gökten, Soner (2016), "Entegre Raporlama Yaklaşımı İçin Uygulamaya Yönelik Sistematik Bir Öneri”, Muhasebe Bilim Dünyası Dergisi, Cilt:18, Sayı:4, ss.741 - 765.

Haller, Axel- Staden, Chris Van (2014), "The Value Added Statement-An Appropriate İnstrument For İntegrated Reporting" Accounting, Auditing \& Accountability Journal, Vol:27, No:7, ss.1190-1216.

Havlová, Kristýna (2015), "What Integrated Reporting Changed: The Case Study of Early Adopters", Procedia Economics and Finance, Issue: 34, pp. 231 - 237.

IIRC (2013), “The International IR Framework", Çevrimiçi http://integratedreporting.org/wpcontent/uploads/2015/03/13-12-08-THE-INTERNATIONAL-IR-FRAMEWORKTurkish.pdf (2 Aralık 2017).

IIRC (2018), Çevrimiçi examples.integratedreporting.org/recognized_reports (Erişim Tarihi: 25 Mart 2018).

IIRC (2018), Çevrimiçi integratedreporting.org/ir-networks/ (25 Mart 2018).

Karğın, Sibel-Aracı, Hakan-Aktaş, Hüseyin (2013), "Entegre Raporlama: Yeni Bir Raporlama Perspektifi", Muhasebe ve Vergi Uygulamaları Dergisi, Sayı:1, ss. 27-46.

Kaya, Pınar (2015), "Entegre Raporlama Sisteminin Ortaya Çıkış Sebepleri Ve Şirketlere Sağlayacağı Faydalar", Muhasebe ve Denetime Bakış Dergisi, ss. 113-130.

Kaya, Uğur-Aygün, Davut-Yazan, Ömer, (2016), "Yeni Bir Kurumsal Raporlama Yaklaşımı Olarak Entegre Raporlama ve Dünyadaki Uygulama Örnekleri Üzerine Bir Araştırma”, KTÜ Sosyal Bilimler Enstitüsü Sosyal Bilimler Dergisi, Cilt:6, Sayı:11, ss.85-101.

KPMG (2017), "The Road Ahead: The KPMG Survey of Corporate Responsibility Reporting", https://assets.kpmg.com/content/dam/kpmg/xx/pdf/2017/10/kpmg-survey-ofcorporate-responsibility-reporting-2017.pdf (4 Nisan 2018).

Köse, E.-Çetinel, T . (2017), "Kurumsal ve Entegre Raporlama: Bir Araştırma", Siirt Üniversitesi Sosyal Bilimler Enstitüsü Dergisi, Cilt:5, Sayı:8, ss.155-181.

Malgwi ,Charles A.-Purdy Derek, E.(2009), "A Study of The Financial Reporting Dichotomy of Managers' Perceived Usefulness Of The Value Added 157 Statement", Business and Society Review, Vol:114, Issue:2, pp.253- 272.

Mio, Chiara-Marco, Fasan -Pauluzzo , Rubens (2016), "Internal Application of IR Principles: Generali's Internal Integrated Reporting", Journal of Cleaner Production, No:139 pp.204-218. 
Mook, Laurie- Richmond, Jane Betty- Quarter, Jack (2003), “Integrated Social Accounting for Nonprofit : A Case Form Canada", Voluntas:İnternational Journal of Voluntary and Nonprofit Organization, Vol:14, No:3,pp.283-297.

Önce, Saime-Ahmet Onay- Gül Yeşilçelebi (2015), "Kurumsal Sürdürülebilirlik Raporlaması ve Türkiye'deki Durum”, Journal of Economics, Finance and Accounting, Vol:2, pp.230-252.

Özdemir, Zehra-Pamukçu, Fatma (2016), "Kurumsal Sürdürülebilir Raporlama Sisteminin Borsa İstanbul Sürdürülebilirlik Endeksi Kapsamındaki İşletmelerde Analizi”, Mali Çözüm Dergisi, ss. 13-35.

Öztürk, Seçil (2011), “Firma Düzeyinde Katma Değer Hesaplaması ve Seçilmiş Muhasebe Standartları Açısından Kit'ler Üzerinde Bir İnceleme”, Gazi Üniversitesi Sosyal Bilimler Enstitüsü, (Yayınlanmamış)Yüksek Lisans Tezi, Ankara.

Ruiz-Lozano, Mercedes- Tirado-Valencia, Pilar (2016), "Do İndustrial Companies Respond To The Guiding Principles Of The Integrated Reporting Framework? A Preliminary Study On The First Companies Joined To The Initiative" Revista de Contabilidad Spanish Accounting Review, Vol:19, Issue:2, pp.252-260.

Serafeim, George (2014), Integrated Reporting and Investor Clientele, Harvard Business School Working Paper, No. 14-069.

Staden, Chris Van-Haller, Axel- Landis, Cristina (2013), "Value Added information as part of Sustainability reporting - initial international insights", The seventh Asia Pacific Interdisciplinary Research in Accounting Conference, Kobe.

Topçu, Mustafa Kemal-Korkmaz, Göksel (2015), "Entegre Raporlama Kavramsal Bir İnceleme", Dokuz Eylül Üniversitesi İktisadi ve İdari Bilimler Fakültesi Dergisi, Cilt:30, Say1:1, ss.1-22.

Yanık, Serhat-Türker, İpek (2012), "Sürdürülebilirlik ve Sosyal Sorumluluk Raporlamasındaki Gelişmeler (Tümleşik Raporlama)", İ.Ü. Siyasal Bilgiler Fakültesi Dergisi, No:47, ss.291-308.

Yüksel, Filiz-Arac1, Hakan (2017), "Entegre Raporlama, Türk İşletmelerinin Entegre Raporlamaya Bakışı Üzerine Bir Araştırma”, Yönetim Ve Ekonomi, Cilt:24, Sayı:3, ss.741-757. 
EK 1. Katma Değer Tablosu

\begin{tabular}{|c|c|}
\hline \multicolumn{2}{|l|}{ KATMA DEĞER TABLOSU } \\
\hline KATMA DEĞERIN HESAPLANMASI & TUTARLAR \\
\hline Hasılat & \\
\hline (+) Satışların Değeri & \\
\hline i.İşletmenin Esas Faaliyetlerinden Sağlanan Tutarlar & \\
\hline$\square \quad$ Mal Satışları & \\
\hline$\square \quad$ Hizmet Satışları & \\
\hline ii.Yatırım ve Finansman Faaliyetlerinden Sağlanan Tutarlar & \\
\hline$\square \quad$ Faiz, İsim Hakk1 ve Temettüler & \\
\hline (-) Önceki Dönemde Üretilmiş Olan Stoklara ilişsin Satış Değeri & \\
\hline (+) Mevcut Dönemde Üretilerek Stoklanmış Malların Piyasa Değeri & \\
\hline (-) Satın Alınan Mal ve Hizmetlerin Değeri & \\
\hline TOPLAM KATMA DEĞER & \\
\hline KATMA DEĞERIN PAYLAŞIMI & \\
\hline EMEK & \\
\hline Maaş ve Ücretler & \\
\hline SERMAYE & \\
\hline Ortaklara & \\
\hline -Temettü & \\
\hline İşletmeye Kalan & \\
\hline - Amortismanlar ve Dağıtılmayan Karlar & \\
\hline Borç Verenlere & \\
\hline -Faiz, Komisyonlar, Vade Farkları, Kur Farkları & \\
\hline DEVLET & \\
\hline Dönem Vergi Gideri & \\
\hline
\end{tabular}

Kaynak: Öztürk, Seçil (2011). "Firma Düzeyinde Katma Değer Hesaplaması Ve Seçilmiş Muhasebe Standartları Açısından Kit'ler Üzerinde Bir İnceleme”, Gazi Üniversitesi Sosyal Bilimler Enstitüsü, (Yayınlanmamış)Yüksek Lisans Tezi, ss.146-147. 